\title{
Meerduidig en meervoudig
}

\section{Interreligieuze en interculturele dialoog in geestelijke verzorging}

\author{
Martin Walton*
}

\begin{abstract}
Summary
Recent publications by Aad de Jong on interreligious dialogue en Anke Liefbroer on interfaith spiritual care offer differing approaches to the field. De Jong advocates a witnessing, dialogical approach by the religious worker in the conversation between members of various religions. Liefbroer assumes a more neutral, facilitating role for the spiritual care giver in a landscape colored by multiple religious belonging. These differences give rise to reflections on the nature of witnessing, both in a personal and professional sense; on the multiple layers of language acts; on the plural nature of identify and religious identification; and on the goals of spiritual care and chaplaincy.
\end{abstract}

\begin{abstract}
Nieuwstad 14
Ik was bezoek dat langer bleef en anders sprak, maar ik misstond niet in de kamer. Een beetje als een schemerlamp die op de duur de sleutel kreeg. Ik deed niet ongezellig en in mijn buurt was het aan tafel minder leeg. Maar nog liet niemand na mij af en toe te wijzen op mijn tong, mijn grond. Dan noemden ze mij onverwachts weer anderman en zonden mij naar huis, terwijl ik juist begon te wennen aan de lucht en onderhand ook dacht dat ik een hart veroverd had. Maar niets was minder waar dan dat. Op tijd en stond werd naar mijn stoel gekeken, gepolst of ik al wortel schoot. Ik hield mijn mond en vond het krassen van de meeuwen geen goed teken. Hoe kwam het dat ik binnen zat en tegelijk nog buiten stond.
\end{abstract}

Bart Moeyaert

\footnotetext{
* Martin Walton is emeritus hoogleraar geestelijke verzorging aan de Protestantse Theologische Universiteit in Amsterdam en Groningen.
} 
Wat als wij het gedicht van Nieuwstad 14 lezen vanuit het gezichtspunt van interreligieuze (en interculturele) dialoog? Er is sprake van gastvrijheid; er is gewenning aan elkaar, wederzijdse belangstelling en kennelijk is er ook van hart tot hart gesproken. Maar er worden ook grenzen getrokken. Het lijkt alsof de 'ik-figuur' dacht dat hij of zij aan het integreren was en binnen zat, maar op een gegeven moment ontdekt dat hij/zij toch buiten staat. In de dialoog en in de omgang is er heel veel gelukt, maar binnen bepaalde perken die als buitensluitend ervaren worden.

Met Nieuwstad 14 als vertrekpunt keer ik naar twee zeer verschillende verkenningen van interreligieuze dialoog die recentelijk in Nederland verschenen zijn. De eerste is de praktisch-theologische benadering van Aad de Jong die in 2019 postuum en onvoltooid (onder redactie van Ren Lantman) verschenen is, Getuigen van de Geest. Een praktisch theologische benadering van interreligieuze dialoog. Het tweede is het proefschrift van Anke Liefbroer, Interfaith spiritual care, dat in september 2020 aan de VU Amsterdam verdedigd werd. In wat volgt ga ik vooral in gesprek met Aad de Jong die zich breed bezint op de voorwaarden van interreligieuze dialoog, als handreiking aan mensen die een religieus beroep uitoefenen. Het empirisch onderzoek van Liefbroer helpt om nader in te gaan op de praktijk van interreligieuze geestelijke verzorging. In deze twee publicaties ziet men twee polen van de, overigens wat publicaties betreft, spaarzame discussie over interreligieuze geestelijke verzorging in Nederland; enerzijds een meer getuigende, dialogische benadering waar De Jong voor pleit en anderzijds een meer neutrale, faciliterende benadering, zoals uit het empirisch onderzoek van Liefbroer naar voren komt. Ook hun beeld van het religieuze landschap verschilt. Waar De Jong voornamelijk van identificeerbare religieuze tradities uitgaat, legt Liefbroer nadruk op meervoudige religieuze identificaties. Omdat de opvattingen van De Jong en Liefbroer twee min of meer paradigmatische posities ten aanzien van interreligieuze geestelijke verzorging in Nederland vormen, biedt een vergelijkende lezing, waar dat mogelijk is, een vruchtbaar uitgangspunt voor verdere discussie.

Vertrekpunt voor mijn bespreking hier is echter het centraal stellen door De Jong van het begrip getuigen. Getuigenis verstaat hij als een interactieve taalhandeling in een dialoog gericht op participatie in het verhaal van mensen en God. Het doel van participatie maakt dat hij kritisch staat tegenover een benadering van interreligieuze dialoog vanuit het begrip identiteit waarin hij een terugtrekkende beweging ziet. Ik wil hieronder op deze cluster van begrippen ingaan. De benadering van Liefbroer, en van enkele anderen, zal ik inbrengen, om verschillende betekenissen van de begrippen te verkennen 
en andere posities te verdisconteren. Het doel is om door bespreking van de begrippen tot een nadere inkleuring van de beroepspraktijk van (interlevensbeschouwelijke) geestelijke verzorging te komen, deels formeel, deels inhoudelijk. Voorop staat - meer formeel - een waarnemende en faciliterende rol van de geestelijk verzorger, waarin echter - meer inhoudelijk - de persoonlijke en professionele attestaties van een geestelijk verzorger gevraagd kunnen worden. Daarin vormt het begrip pluraliteit een belangrijke sleutel. Om de begrippen te verkennen en tot een eigen positiebepaling te komen, bespreek ik een viertal kwesties:

(1) Geestelijke verzorging als gekwalificeerde dialoog. Past de invulling van de term 'getuigen' als een spreken over persoonlijk geloof, door De Jong bij de (faciliterende) praktijk van geestelijke verzorging? En vormt de accentverschuiving in geestelijke verzorging van religieuze naar existentiële kwesties, waar Liefbroer over schrijft, voor de benadering van De Jong een uitdaging? Ik onderscheid hierbij waarneming en attestatie als verschillende vormen van getuigen om faciliterende en dialogische rollen van de geestelijk verzorger aan te duiden.

(2) Helderheid en meerduidigheid in taal. De Jong benadrukt taalkundige precisie in het onderscheiden van verschillende soorten taalhandelingen. Daar kunnen geestelijk verzorgers van leren. Maar de vraag is ook hoe zulke precisie zich verhoudt tot (a) het 'poëtische' maar soms ook 'slordige' taalgebruik van mensen als ze hun 'verhaal' vertellen en (b) de polyvalentie van religieuze taal, rituelen en symbolen. Ook met betrekking tot interpretatie van taaluitingen onderscheid ik een faciliterende en een attesterende rol van de geestelijk verzorger.

(3) Het begrip identiteit en religieuze identificaties van geestelijk verzorgers. De Jong acht de nadruk op identiteit eerder een hindernis dan een hulp voor dialoog. In plaats daarvan stelt hij de term participatie centraal, maar spreekt ook bij gelegenheid van een 'participatieve identiteit' Liefbroer onderscheidt een particularistische benadering van interreligieuze zorg vanuit een specifieke religieuze binding en een universalistische benadering vanuit een open, overstijgend religieus perspectief. Waar het onderscheid van De Jong de persoonlijke identiteit raakt, heeft het onderscheid van Liefbroer meer met de religieuze identificatie van de geestelijk verzorger als professional te maken. Zowel in het conceptualiseren van identiteit als in het waarderen van verschillende vormen van levensbeschouwelijke identificatie kan het begrip pluraliteit een bemiddelende rol spelen. Omdat het perspectief vanuit pluraliteit intrinsieke betekenis voor de beroepsuit- 
oefening heeft, kan men van 'professionele attestatie' spreken met het oog op waar het beroep voor staat.

(4) Doelen van geestelijke verzorging. De Jong poneert 'participatie' als doel van interreligieuze dialoog. Opvallend is dat Liefbroer niet over de doelen van (interreligieuze) geestelijke verzorging schrijft. Om over de doelen van geestelijke verzorging meer te kunnen zeggen introduceer ik een onderscheid van Smeets tussen een direct doel van geestelijke zorg, namelijk, levensbeschouwelijke communicatie, en een ultiem doel, namelijk, geestelijk welzijn. Hoewel de benadering van Smeets in eerste instantie faciliterend bedoeld is, staan zijn formuleringen open voor attestatie. Ik doe een voorstel tot herformulering van de doelen van geestelijke verzorging waarin de door Smeets en De Jong genoemde doelen aan elkaar gerelateerd worden.

\section{Waarvan getuigen? Geestelijke verzorging als gekwalificeerde dialoog}

\subsection{Getuigen van persoonlijk geloof}

Hoewel in meerdere passages in het boek van De Jong geestelijke verzorging ter sprake komt is er slechts één alinea in het onvoltooide werk dat expliciet een nadere bepaling van geestelijke verzorging biedt. Daarin bekritiseert De Jong de benadering, zoals bij Ganzevoort en Visser (2007) te vinden is, namelijk dat geestelijke zorg verbanden dient te leggen tussen het verhaal van mensen en het verhaal van God (De Jong 2019, 116). Daarvoor geeft hij twee redenen. Ten eerste benadrukt De Jong dat er slechts één verhaal van God en mensen is. Deze principiële positie past bij de verwijzing van De Jong naar de uitspraak van Schoonenberg: "God en mens concurreren niet.” Hoewel de kritiek hier niet uitgewerkt wordt, lijkt die erop gericht te zijn dat een hermeneutische, narratieve benadering, die verbanden tussen verhalen probeert te leggen, de fundamentele eenheid in het verhaal van God en mensen miskent (De Jong 2019, 211)

Ten tweede lijkt De Jong kritisch te staan tegenover een narratieve benadering als zodanig. Over het verhaal van God en mensen merkt hij op: "voor zover het een verhaal is.” Bovendien vindt hij geestelijke zorg niet een kwestie van verhalen vertellen (hetgeen wat reductionistisch uitgedrukt is) maar van geloof als een "attestatieve hulpdienst door religieus werkers aan het persoonlijk geloof van mensen waarvoor en waarmee ze werken.” Dat deze hulp 
dialogisch bedoeld is, blijkt uit het vervolg "dat die hulp niet uitsluitend van één 'verhaal van God'” hoeft te komen. ${ }^{1}$

Veel verder reikt de expliciete bespreking van geestelijk verzorging bij De Jong niet, maar met de term 'attestatie' verbindt De Jong zijn visie op geestelijke verzorging met 'getuigenis', een kernbegrip van zijn boek. Dat de term 'getuigen' centraal staat in De Jongs praktisch theologische benadering van de interreligieuze dialoog, blijkt al uit de titel van het boek, Getuigen van de Geest. Wat verstaat De Jong onder getuigen? In plaats van in te gaan op de taaltheoretische beschouwingen van De Jong (op het werk van Searle gebaseerd), probeer ik te verstaan wat bij getuigen op het spel staat. In het getuigen wordt iets naar voren gebracht, iets beweerd, dat - naar de overtuiging van de spreker - overeenkomt met de werkelijkheid. De getuigenis wordt bovendien afgelegd in een situatie waarin iets op het spel staat: een oordeel of beslissing met gewicht. Getuigen is dus voor De Jong niet het naar voren brengen van een vermoeden of een gevoelen, maar een cognitieve aangelegenheid (De Jong 2019, 72-74).

Van hieruit oefent De Jong kritiek op het attestatiebegrip van Huijzer, die, met een beroep op Ricoeur, attestatie sterk verbindt met "de innerlijke zekerheid van het zelf" en de dialoog van het zelf met het zelf (Huijzer 2017, 188 e.v.). De Jong meent dat Huijzer de reikwijdte van attestatie onvoldoende ontvouwt. Het punt van De Jongs kritiek is - terecht of niet - dat attestatie niet als een expressie (van de beleving) van het zelf, en niet als uitdrukking van motivatie en inspiratie in dienst van de eigen identiteitsontwikkeling te verstaan is, maar als een dialogische (taal)handeling in wisselwerking met de omgeving. Kort gezegd, het gaat niet (alleen) om 'authenticiteit' (hoewel De Jong het begrip van Taylor in dit verband niet gebruikt) maar (ook) om 'commitment', 'talig religieus commitment' (De Jong 2019, 46). Er staat iets op het spel en er valt iets substantieels mee te delen. Attestatie slaat niet in de eerste plaats op het zelf maar vooral op de interactie.

Bij getuigen gaat het voor De Jong - in mijn woorden - om zienswijzen en zijnswijzen die ertoe doen, die niet zomaar als subjectieve voorkeuren gerelativeerd kunnen worden, of als sociale constructies afgedaan. Aan geloven kent hij weliswaar subjectieve maar ook 'ontologische' betekenis toe (De Jong 2019, 110). Dat De Jong in dit kader ook over 'levensverwerkelijking' spreekt maakt duidelijk dat de invalshoek weliswaar talig is, maar dat de talige dialoog moet leiden tot participatie en coöperatie in de geschiedenis van mensen en God, waarin het gaat - in het teken van het rijk van God - om de vermenselijking van die geschiedenis, "ter opbouw in onze sociale werkelijkheid." Dat is wat er voor De Jong op het spel staat. 


\subsection{De rol van het religieuze}

Een mogelijke uitdaging aan de nadruk van De Jong op attestatieve hulp aan het persoonlijk geloof van mensen biedt de conclusie van Anke Liefbroer dat er een verschuiving plaatsvindt in geestelijke verzorging van religieuze naar existentiële thema's. In de meeste praktijken van spirituele zorg spelen religieuze en spirituele thema's en verschillen een ondergeschikte rol (Liefbroer 2020, 196-198). Wat zou dan nog de plaats van attestatie of getuigenis zijn? Gaat spirituele of geestelijke zorg nog wel over 'geloof'? En wat is geloof? Het onderzoek van Liefbroer naar meervoudige religieuze identificaties maakt duidelijk dat het religieuze landschap diffuus is, ook als zij het in termen van definieerbare religies onderzoekt. Dat lijkt De Jong te onderkennen daar waar hij minder verwacht van vergelijkende godsdienstwetenschap en meer van onderzoek naar het persoonlijk geloof van mensen (De Jong 2019, 213). Tegelijk is het met zijn nadruk op het cognitieve aspect van getuigenis niet altijd duidelijk wat de inhoud van een attestatie zou zijn, of van welke geestelijke bron die afkomstig is. Is 'geloof', bijvoorbeeld, op te vatten als een particuliere overtuiging (of praktijk), of in de zin van Tillich (1957) en Fowler (1981) als een existentiële positiebepaling?

Met het spreken over geloof als een existentiële positiebepaling lijken de bevindingen van Liefbroer minder in tegenstelling te staan. Gaan gesprekken in geestelijke verzorging niet al veel langer grotendeels over existentiële en alledaagse vragen?3 ${ }^{3}$ Het geestelijke of spirituele van die zorg is dan niet (altijd) een expliciete verwijzing naar een specifieke religie of levensbeschouwing, maar de manier waarop men daarover spreekt en de relaties die er met zingeving gelegd worden. Anders gezegd: spirituele zorg is niet het spreken over spirituele dingen maar het spiritueel spreken over de dingen. ${ }^{4}$

\subsection{De aard van het getuigen}

Dan blijft nog de vraag hoe een interreligieuze of interlevensbeschouwelijke ontmoeting in het kader van geestelijke verzorging zich verhoudt tot de karakterisering van interreligieuze dialoog door De Jong met zijn nadruk op attestatie. Van geestelijk verzorgers wordt volgens de beroepstandaard verwacht dat zij rekenschap kunnen afleggen van hun positiebepaling inzake existentiële, ethische en spirituele vragen (VGVZ 2015, 15). In termen van de beroepscode: "De geestelijk verzorger zelf is in het geding in het contact met cliënten, naasten en medewerkers. De geestelijk verzorger is derhalve aanspreekbaar op wie zij zelf is en waar zij zelf (voor) staat" (VGVZ 2015, 20). Dat zijn attestatieve aspecten van de beroepsuitoefening. 
Tegelijk zijn geestelijk verzorgers vanuit hun beschikbaarheid voor alle personen, van welke levensovertuiging dan ook, terughoudend met het inbrengen van hun eigen overtuigingen. Ook vanwege de asymmetrie en de machtsongelijkheid tussen de geestelijk verzorger en de ander. (VGVZ $2015,20)$. Geestelijk verzorgers richten zich primair op de existentiële noden of vragen van de gesprekspartner en op diens (bronnen van) zingeving en levensbeschouwing. Alleen daar waar het behulpzaam of functioneel is, komt self disclosure door de geestelijk verzorger aan de orde. Dat geldt ook voor de levensbeschouwelijke attestatie of getuigenis van de geestelijk verzorger. In geestelijke verzorging is er sprake van dialoog maar bedacht moet worden dat het de dialoog is van weliswaar gelijkwaardige maar tegelijk ongelijksoortige gesprekspartners. Dit is niet ongelijk aan de typering van Buber van de hulpverleningsrelatie als een gekwalificeerde vorm van de dialogische relatie, met een "normatieve beperking van de wederkerigheid" (Buber 1962, 167-168).

Het kenmerkende van het 'getuigen' van geestelijk verzorgers is het opschorten van de eigen getuigenis (het eigen oordeel of de eigen beslissing) om eerst 'getuige' te kunnen zijn van de situatie, de vragen én de zingeving (of worsteling ermee) van de ander (Dittes 1999). Dit faciliterend gebruik van de term getuigenis is functioneler en wellicht, zoals Liefbroer opmerkt, vaak minder expliciet religieus dan het gebruik ervan door De Jong. Ook dit getuigen is constaterend maar heeft niet hetzelfde ontologische, attestatieve karakter als bij De Jong. Het faciliterende getuigen speelt vaak een rol in persoonlijke begeleiding, maar ook in moreel beraad, in teambegeleiding en advisering. Daarin wordt recht gedaan aan de eis van De Jong dat er in het getuigen een sociaal commitment is, maar de waarneming en weergave (getuige zijn) van de getuigenis van anderen staat voorop. De geestelijk verzorger faciliteert, is dienstbaar aan de dialoog die gevoerd wordt. Daarbij kan het gaan om de dialoog in een groep, zoals in moreel beraad, of de ondersteuning die een geestelijk verzorger biedt aan de innerlijke dialoog van een individu.

Tegelijk is de geestelijk verzorger getraind om te onderscheiden waar het op aan komt. De getuigenissen gaan ergens over. Er staat iets op het spel. Ook als waarnemende getuige is de geestelijk verzorger zelf in het geding. Daar waar nodig zal de geestelijk verzorger als attesterende getuige laten merken dat er iets op het spel staat en wat er op het spel staat, én waar hij of zij zelf staat. Niet dwingend, maar dialogisch. Dat lijkt me een correctie die De Jong aanbrengt daar waar de dialoog te subjectivistisch of constructivistisch wordt opgevat. De kunde van het vak is om vanuit de rol van waarnemer en facilitator te onderkennen waar en wanneer een meer attesterende inbreng wenselijk is. De getuigende rol van de geestelijk verzorger is dus wat vorm betreft meervoudig. 


\section{Helderheid en meerduidigheid in taal}

Het pleidooi dat De Jong voor helderheid van taalgebruik in het eigen spreken voert, is zeer welkom en voor de waarnemende en faciliterende rol van de geestelijk verzorger onontbeerlijk. De Jong baseert zich op de taalkundige theorie van Searle, die verschillende ideaaltypen van talige handelingen en interactie onderscheidt. Die onderscheidingen helpen De Jong om getuigenissen van adviezen te onderscheiden, expressieve uitingen van voornemens, enz. (De Jong 2019, 74). Van belang is mijns inziens om niet alleen ideaaltypen in formele zin te identificeren maar om met behulp van de ideaaltypen verschillende lagen in de communicatie te onderscheiden, vaak binnen de ene taalgebeurtenis of taaldaad. Het is de interpretatieve kunst van de geestelijk verzorger om in het taalgebruik van de ander die verschillende lagen te horen en te onderscheiden, of waar dat moeilijk gaat, ernaar te vragen. Liefbroer biedt geen beschouwing over de taal en taalgebruik maar zij identificeert wel verschillende communicatieve technieken gericht op verheldering of explicitering van de levensbeschouwelijke oriëntatie van de ander (Liebroer 2020, 180181) die het werk van onderscheiden en interpreteren kunnen ondersteunen.

In de regel moet men altijd een aantal keren naar de ene uiting luisteren. Ten eerste, naar wat de ander zegt, de inhoud. Ten tweede, naar de grammaticale vorm waarin de ander wat zegt. Ten derde, naar de affectieve lading waarmee iets gezegd wordt. Ten vierde, naar de context, ook het moment in de tijd, waarin de ander iets zegt. Ten vijfde, naar wat de ander ermee wil, eventueel vanuit welke strategische overwegingen. Ten zesde, naar wat verborgen blijft. Ten zevende, naar de onderliggende en mogelijke zingevende veronderstellingen. Kortom, meer dan De Jong zou ik de complexiteit, maar ook de 'messiness' van de menselijke communicatie willen benaderen, binnen een enkele talige vorm. Om aan die complexiteit recht te doen wordt het waarnemende en faciliterende getuigen van de geestelijk verzorger opnieuw uitgedaagd.

Het zou kunnen zijn dat de bedenkingen van De Jong ten aanzien van narratieve benaderingen samenhangen met zijn streven naar heldere regels in de dialoog. Hier zou ook nog meer te vragen zijn naar zijn opvatting van religie. Want houdt hij voldoende rekening met het 'slordige' taalgebruik van mensen als ze hun 'verhaal' vertellen, en hun gebruik van poëtische middelen die beeldend, meerduidig en fragmentarisch zijn? En houdt hij voldoende rekening niet alleen met de meerduidigheid van religieuze en alledaagse taal, maar ook met de polyvalentie van religieuze taal, rituelen en symbolen? Daarmee rekening houden vraagt niet alleen om het onderscheiden en bezigen van verschillende typen taaluitingen, inclusief getuigenissen (De Jong), maar ook 
om technieken om in de talige communicatie verschillende lagen te onderscheiden (Liefbroer 2020) en de meerduidigheid in levensbeschouwelijke taal te onderkennen.

\section{Het begrip identiteit en religieuze identificaties}

\subsection{Naar een plurale opvatting van identiteit}

Het begrip identiteit acht De Jong eerder een hindernis dan een hulp voor dialoog. De suggestie is dat identiteit tot een zich terugtrekken op eigen terrein leidt, een nadruk op het onderscheidende. In plaats van identiteit als leidend principe van dialoog stelt De Jong 'participatie' voor. Dit onderscheid loopt parallel aan dat tussen authenticiteit en commitment. Identiteit roept concurrentie op in plaats van samenwerking. Daarbij legt De Jong niet alleen nadruk op religieuze aspecten maar ook op de sociale en historische dimensies van onze geschiedenis (met God) (De Jong 2019, 22 e.v.).

Het onderscheiden tussen identiteit en participatie is zowel verhelderend als beperkend. Het verheldert het belang van gemeenschappelijkheid en samenwerking. Het suggereert echter dat identiteit voornamelijk in uniciteit te vinden is, hetgeen slechts een deel van het verhaal is. Dat lijkt De Jong aan te voelen als hij een enkele keer de term 'participatieve identiteit' bezigt (De Jong 2019, 187; de term komt ook op p. 205 in de publicatielijst voor: De Jong 2007). De term 'participatieve identiteit' suggereert namelijk de mogelijkheid van een synthese bij zijn eigen antithetische formulering van identiteit en participatie.

Een manier om een synthese te formuleren wordt door Emmanuel Lartey (2007) geboden. In zijn interculturele benadering van pastorale zorg formuleert Lartey een drieslag waarin hij veronderstelt dat ieder mens in sommige opzichten (a) op alle andere mensen lijkt (gedeelde menselijkheid en waardigheid); (b) op sommige anderen lijkt (gemeenschappelijkheid); én (c) op niemand anders lijkt (uniciteit). Daarmee is identiteit niet tot het onderscheidende of unieke gereduceerd, maar omvat evenzeer gemeenschappelijke en basale antropologische kenmerken. (Voor een eerdere bespreking hiervan in Religie a Samenleving, zie Walton 2017.) Een dergelijk verstaan van identiteit levert in zichzelf geen constructieve samenwerking of participatie op, in de zin die De Jong voor ogen staat, maar het laat zien dat mensen (passief én actief) reeds deel uitmaken van een gezamenlijke geschiedenis van mensen (en God). Kortom, het participatief aspect is reeds met de identiteit 
meegegeven. De term 'participatieve identiteit', zoals De Jong die hanteert, wordt dan pleonastisch.

De benadering van Lartey biedt kritiek op iedere versmalling van identiteit. En zij maakt duidelijk dat het bestaan maar ook het begrip van het 'zelf' van de ander afhankelijk is, en ook afhankelijk van het anders-zijn van de ander. In ieder verstaan van de aspecten van uniciteit én van gemeenschappelijkheid én van (gedeelde) menselijkheid zijn ontelbare anderen mee geïmpliceerd. Daarmee ontstaat een identiteitsbegrip dat in zichzelf pluraal (meervoudig) is: verankerd én open.

\subsection{Naar een plurale benadering van religieuze identificatie onder geestelijk verzorgers}

De benadering van Lartey helpt ook bij het onderscheid dat Liefbroer maakt tussen twee soorten benaderingen in interreligieuze geestelijke verzorging, een particularistische en een universalistische (Liefbroer 2020, 24). Een particularistische benadering veronderstelt een identiteit die gekenmerkt wordt door verbinding met een specifieke religie of spiritualiteit en een zorgbetrekking binnen dezelfde spirituele achtergrond. Een universele benadering veronderstelt een identiteit met een open houding en een zorgbetrekking in termen van spirituele verbinding en met handelingen die een specifieke religie overstijgen. In een vervolgonderzoek door Liefbroer blijkt dat geestelijk verzorgers optimistisch ('positief') waren met het oog op hun vermogen om interreligieuze spirituele zorg te bieden, al waren geestelijk verzorgers met een meer eenduidige religieuze binding iets minder optimistisch over hun competentie om interreligieuze spirituele zorg te bieden. (Liefbroer 2020, 78) Interessant is dat in de waardering door cliënten er vervolgens geen significant onderscheid gevonden werd tussen spirituele zorg door iemand van dezelfde spiritualiteit of religie en zorg door iemand van een andere oriëntatie (Liefbroer 2020, 139).

Deze resultaten suggereren dat in de praktijk dingen dichter bij elkaar zitten dan de theoretische onderscheidingen zouden vermoeden. Mijns inziens staan zij ook open voor een formulering van een positie tussen het particularistische en het universalistische, namelijk, het pluralistische (vgl. Oostveen 2017). Erkenning van het pluralisme is namelijk wat anders dan het onderschrijven van een universalistische of overstijgende 'meta-discours', mede daardoor dat die ruimte laat voor particuliere posities of getuigenissen (Boeve 2005 , 99). Ruimte bieden aan particuliere overtuigingen is ook wat anders dan een particularistisch zich terugtrekken in een specifieke religieuze identiteit. De aanvaarding van het levensbeschouwelijke pluralisme, inclusief samen- 
gestelde en diffuse zingeving, lijkt mij de gemeenschappelijke professionele grond waarop de breedte van de beroepsbeoefenaars van geestelijke zorg zich bevinden. Zij zijn beschikbaar voor iedereen en het hoort tot de professionele competenties van iedere geestelijk verzorger om interlevensbeschouwelijke zorg te kunnen bieden, onafhankelijk van de achterliggende visies of van de mate van optimisme over eigen competentie. Een dergelijke pluralistische benadering laat als spiegel van een pluraal identiteitsbegrip ruimte voor verankering (specificiteit, particuliere getuigenissen) én openheid (respect voor en dialoog met een meervoud van levensbeschouwelijke posities).

Liefbroer constateert dat in de praktijk geen eenduidige verschillen in de empirische data werden gevonden met het oog op de wijze van bevoegd verklaren ('authorization') van geestelijke verzorgers (2020). Aan die constatering verbindt Liefbroer de conclusie dat het belang van 'authorization' van geestelijk verzorgers en de precieze rol en functie ervan, in een geseculariseerde en gepluraliseerde maatschappij als Nederland onduidelijk zijn. Feitelijk kent de beroepsstandaard twee mogelijkheden van bevoegd verklaren of authorization: zending door een levensbeschouwelijke organisatie of machtiging door een daarvoor aangewezen instantie (RING) (VGVZ 2015), maar Liefbroer lijkt de eerste op het oog te hebben. De suggestie lijkt te zijn dat een particuliere zending nu betekenis mist en belang verliest. Blijft men echter bij een pluralistische benadering dan is ruimte en respect voor het huidige pluralisme in het bevoegd verklaren wellicht aan te bevelen. Dat lijkt ook beter aan te sluiten bij het verschijnsel van meervoudige religieuze identificaties waar Liefbroer op wijst (zie boven onder 1.), dat zich tussen een particularistische en een universalistische benadering kan bevinden. Pluraliteit wordt niet alleen getolereerd, maar beaamd.

\subsection{Pluralisme als professioneel perspectief}

Een pluralistische opvatting van identiteit (tegenover De Jong in 3.1.) vindt een weerspiegeling in een pluralistische benadering van de manier waarop geestelijk verzorgers zich met levensbeschouwelijke tradities identificeren (tegenover Liefbroer in 3.2). Zo ontstaat een intrinsieke relatie tussen de beroepspraktijk van geestelijke verzorging en (levensbeschouwelijke) pluraliteit, bijvoorbeeld in beschikbaarheid en begeleiding, in identificatie en in samenstelling van teams. Omdat pluraliteit niet alleen erkend en getolereerd wordt maar ook in de praktijk beaamd wordt en vorm krijgt, zou ik van een professionele attestatie of getuigenis ${ }^{5}$ van geestelijk verzorgers ten aanzien van pluraliteit willen spreken, passend bij de participatieve gerichtheid op dialoog. 


\section{Doelen van geestelijke verzorging}

Het doel van interreligieuze dialoog dat De Jong voor ogen heeft is participatie en samenwerking. Kan een dergelijk doel voor geestelijke verzorging van betekenis zijn? Smeets $(2006 ; 2007)$ heeft een onderscheid gemaakt tussen een direct doel van geestelijke zorg, namelijk, levensbeschouwelijke communicatie, en een ultiem doel, namelijk geestelijk welzijn. Dat laatste is met name van belang in aansluiting op de (organisatorische) contexten waarin geestelijke verzorging veelal geboden wordt. Op de formulering en bepaling van het directe doel als levensbeschouwelijke communicatie zou van De Jong kritiek te verwachten zijn. Hij bekritiseert namelijk Van der Ven, aan wie de formulering van Smeets schatplichtig is, als Van der Ven 'religieuze communicatie' als algemene functie van de kerk aanmerkt. Nog afgezien van het feit dat het bij Van der Ven om een onderbouwing ervan zou ontbreken, vindt De Jong de aanduiding 'religieuze communicatie' te cognitief en te activistisch. De Jong heeft een meer zinzoekende (N.B. niet een zingevende) functie voor ogen (De Jong 2019, 185-186).

De kritiek van De Jong zou genuanceerd kunnen worden. Religieuze communicatie kent ook symbolische, rituele, esthetische en passieve aspecten. En in geestelijke zorg wordt levensbeschouwelijke communicatie voltrokken in een vorm van samenwerking tussen twee of meer partijen. Belangrijker mijns inziens is het verschil in duiding. Is levensbeschouwelijke communicatie een 'doel' of een 'functie'?

En het ultieme doel? De formulering geestelijk welzijn lijkt niet alleen andersoortig dan de nadruk op participatie, maar ook een andere reikwijdte te hebben. Vraagt men: 'geestelijk welzijn van wie?' dan is het voor de hand liggende antwoord de cliënt, of de cliëntengroep, maar misschien ook medewerkers, of het zorgteam. Men zou zelfs kunnen stellen dat voor het verantwoord spiritueel en ethisch functioneren van een organisatie het geestelijk welzijn van alle betrokkenen een relevant aspect is. Daarbij rijst de vraag of geestelijk welzijn dan zelf een doel is of een middel tot een breder (ultiemer?) doel. En is daarvoor levensbeschouwelijke communicatie niet eveneens als functie van belang? De horizon dijt uit, waardoor het participatieve doel van De Jong met het oog op het inclusieve verhaal van mensen en God in het vizier komt.

Als wij bovendien in acht nemen dat het verlies van maatschappelijke rollen ten aanzien van familie en vrienden, werk en vrijetijdsbesteding, een ingrijpend en beduidend neveneffect van ziekte, beperking of opsluiting is, dan is het doel van participatie een zinvol perspectief. In de ggz en in de zorg voor mensen met een beperking spelen voortdurend vragen naar maatschap- 
pelijke integratie een grote rol. En daar waar men afhankelijk wordt van een instelling of zorggemeenschap dienen zich ook vragen aan naar de plaats van iemand in die zorggemeenschap. Ook voor medewerkers is de kwaliteit van hun participatie in een organisatie een voortdurende kwestie. Kortom, ook al heeft opname of opsluiting een isolerende werking, de gemeenschap en de maatschappij zijn altijd aanwezig (Ewan \& Swinton 2020).

De vraag is hoe doelen geformuleerd kunnen worden om recht te doen aan de verschillende invalshoeken van De Jong en Smeets. In alle voorlopigheid doe ik een poging met een drieslag. Daarin zie ik geen hiërarchie, waardoor ik woorden als direct en ultiem niet zal gebruiken. Bovendien lijkt me dat in het kader van geestelijke zorg levensbeschouwelijke communicatie en attestatie met het oog op betekenisgeving en waarden, inclusief existentiële, ethische, spirituele en esthetische dimensies, bij alle drie doelen een rol spelen.

- Identiteit. Ten eerste is er een doel gericht op ondersteuning en verheldering met het oog op iemands identiteit in relatie tot diens zelfverstaan, (precaire) situatie en eigen (levensbeschouwelijke) bronnen. Daarin spelen menselijke waardigheid en integriteit een cruciale rol, eveneens een besef dat identiteit naast unieke ook gemeenschappelijke elementen omvat. Ook de identiteit van een organisatie kan een focus van ondersteuning zijn.

- Welbevinden. Ten tweede is er een doel gericht op welbevinden, in de eerste plaats mentaal of geestelijk welbevinden, maar ook met oog voor somatische en psycho-sociale aspecten van welbevinden (Vgl. Richtlijn 2018, 3-4). Net als in het geval van identiteit kan ook een woongroep, een team of een organisatie een mogelijke focus van ondersteuning zijn.

- Ten derde is er een doel met het oog op participatie. Deels bieden levensbeschouwelijke kaders en organisaties zelf mogelijkheden tot participatie. Deels gaat het om ondersteuning bij de rollen die men vervult, naar welke men verlangt of die niet (meer) tot de mogelijkheden horen. Het kan ook gaan om het opgenomen worden in een zorggemeenschap. In alle gevallen is het aanboren van de bronnen van de gemeenschap van belang.

Geestelijke verzorging biedt dan ondersteuning in de manier waarop mensen zich verhouden tot de eigen (of groeps-) identiteit, het welbevinden (of gebrek eraan) en participatie in gemeenschappen en de maatschappij (of belemmeringen daarbij). Daarbij is (inter)levensbeschouwelijke (en culturele) communicatie en attestatie in woord en gebaar, in rituelen en viering, in bezinning en activiteiten de primaire bron van de zorgverlening. De geestelijk verzorger faciliteert die communicatie. Tegelijk zijn de aard van die communicatie en de aard van de doelen niet puur formeel maar veronderstellen zij inhoudelijke 
visies en levensbeschouwelijke activiteiten met een attestatief karakter gericht op inclusie en participatie.

In hetzelfde onderzoek waarin Smeets een tweetal doelen formuleerde, uitte hij zorg om een veelvoorkomende concentratie bij geestelijk verzorgers op de dyadische relatie met een cliënt, gepaard gaande met een individualiserende focus. Wellicht kan de toevoeging van participatie als doel helpen om de dyadische versmalling te doorbreken. Daar waar men oog heeft voor de fundamentele antropologische en zingevende betekenis van participatie, daar waar men oog heeft voor de kwaliteit van de levensbeschouwelijke of zorggemeenschap in het bevorderen van participatie voor zowel cliënten als medewerkers, daar is de geestelijk verzorger niet alleen gericht op individuen binnen dyadische relaties, daar verleent men geestelijke zorg aan de hele gemeenschap met het oog op identiteit, welzijn en participatie. Daarmee houdt geestelijke verzorging in een geseculariseerd en geïndividualiseerd land rekening met mensen uit culturen waarin aan de gemeenschap een grotere waarde wordt toegekend. Daarmee houdt geestelijke verzorging rekening met een landschap waarin meervoudige religieuze en culturele identificaties een toenemende rol spelen. De geestelijk verzorger neemt die verscheidenheid waar en tegelijk kleurt die verscheidenheid de waarneming van de geestelijke verzorger. Opnieuw blijkt dat respect voor pluraliteit een integrale rol speelt in de beroepspraktijk.

\section{Conclusie}

In het gedicht Nieuwstad 14 is, zou men kunnen zeggen, sprake van interculturele communicatie. Aan het welzijn ontbreekt niet veel, maar op het punt van participatie of integratie wordt een voorbehoud gemaakt. Een dergelijke lezing van het gedicht leert ons dat interlevensbeschouwelijke dialoog, ook in het kader van geestelijke verzorging een precair gebeuren is. Het luistert dan ook nauw hoe men het getuigen van de geestelijk verzorger verstaat, het meerduidige van de (religieuze) taal beluistert, kwesties van identiteit in hun meervoudigheid (pluraliteit) onderkent en de doelen van geestelijke zorg met het oog op participatie formuleert. Hoewel de formuleringen met betrekking tot identiteit en doelen hierboven (par. 3 en 4) nog enigszins formeel blijven, impliceren zij meer dan in de beschrijving van een waarnemende of faciliterende taak (par. 1 en 2) is gezegd. De formuleringen 'getuigen', zou men kunnen zeggen, van meer inhoudelijke visies op religieuze taal, op menszijn en identiteit, op de verhouding individu en gemeenschap én daarin steeds op pluraliteit. 
In al deze kwesties blijft uiteraard een zekere bandbreedte van nadere invulling mogelijk, maar het beroep als zodanig staat voor een inhoudelijke en plurale kleuring van identiteit, voor het respecteren van de pluraliteit in levensbeschouwing en cultuur (en in eigen gelederen) en voor het behartigen van doelen gericht op zowel individuen als gemeenschap. De faciliterende taak krijgt ook de kleur van behartigen; het waarnemen vraagt waar mogelijk waarmaken. Dit kan de vorm aannemen van een persoonlijk getuigen, maar is in ieder geval een professionele attestatie als getuigenis van het belang van dialoog en inclusie, anders gezegd van pluraliteit en gerichtheid op participatie, waar de beroepsgroep voor staat. Zo ontstaat een gedifferentieerd, meervoudig beeld van getuigen in geestelijke verzorging, dat rekening houdt met de meerduidigheid van (levensbeschouwelijke) communicatie in de zorgverlening, dat pluraliteit op waarde schat en dat op inclusie en participatie gericht is.

\section{Noten}

1 Aan de voorgenomen uitwerking vanuit het perspectief van het Boeddhisme is De Jong niet toegekomen.

2 Ook Huijzer gebruikt het woord 'commitment' maar in contrast met getuigenis gericht op 'states of affairs of things' (Huijzer 2017, 188). In zijn opvatting van getuigenis benadrukt De Jong overeenkomst met de werkelijkheid.

3 Deze vraag stelde Thijs Tromp als opponent bij de verdediging van haar proefschrift door Liefbroer op 9 september 20202, VU Amsterdam.

4 Ook is de conceptualisering van Liefbroer waarin existentieel en religieus als contrasterende termen worden gebezigd anders dan de conceptualisering in de beroepsstandaard van geestelijk verzorgers waarin het existentiële, naast het spirituele, ethische en esthetische als dimensie van zingeving en levensbeschouwing, inclusief religie, wordt verstaan (VGVZ 2015, 10).

5 Hier zou een verbinding met het begrip 'normatieve professionaliteit' mogelijk zijn. Zie bijv. Kunneman 2006. 


\section{Literatuur}

Buber, M. (1962),

Ich und Du. Nachwort, in: Schriften zur Philosophie. Martin Buber Werke, Erster Band, München: Kösel-Verlag, 161-170.

Boeve, L. (2005),

Religion after Detraditionalization: Christian Faith in a Post-Secular Europe, in: Theological Quarterly, 70, 99-122.

Dittes, J. (1999),

Pastoral Counseling. The Basics, Louisville: Westminster John Knox.

Ewan, K. \& J. Swinton (2020),

Chaplaincy and the Soul of Health and Social Care. Fostering Spiritual Wellbeing in Emerging Paradigms of Care, London: Jessica Kingsley Publishers.

Fowler, J.W. (1981),

Stages of faith: the psychology of human development and the quest for meaning, San Francisco: Harper \& Row.

Huijzer, R. (2017),

De binnenkant van het ambt: Een groundedtheory-onderzoek naar de ambtsbeleving en levensbeschouwelijke identiteit van protestantse pastores in zorginstellingen, in dialoog met Paul Ricoeur, Delft: Eburon.

Jong, A. de (2019),

Getuigen van de Geest. Een praktisch theologische benadering van interreligieuze dialoog, zonder plaatsnaam: Hein Berendsen Public Relations.

Kunneman, H.P. (2006),

Horizontale transcendentie en normatieve professionalisering: de casus geestelijke verzorging, in Donk, W.B.H.J. van de, A.P. Jonkers, G.J. Kronjee \& R.J.J.M. Plum (red.), Geloven in het publieke domein: verkenningen van een dubbele transformatie, WRRverkenning nr.13, Amsterdam: Amsterdam University Press, $367-399$.

Lartey, E. (2003),

In Living Color. An Intercultural Approach to Pastoral Care \& Counseling, London: Jessica Kingsley Publishers.

Liefbroer, A.I. (2020),

Interfaith spiritual care, PhD thesis, Vrije Universiteit Amsterdam.

Oostveen, D.F. (2017),

Multiple Religious Belonging: Hermeneutical Challenges for Theology of Religions, in: Open Theolog $\%, 3$, 38-37.

Richtlijn Zingeving en Spiritualiteit in de zorg (2018),

https://www.pallialine.nl/zingeving-en-spiritualiteit, geraadpleegd 13-10-2020. 
Smeets, W. (2006),

Spiritual Care in a Hospital Setting. An Empirical-Theological Exploration, Leiden: Brill. Smeets, W. (2007),

Geestelijke verzorging: een dyadisch georiënteerde professie op het domein van de spirituele gezondheid, in: Psyche a Geloof, 18 (1-2), 96-113.

Tillich, P. (1957),

Dynamics of Faith, London: Allen \& Unwin.

VGVZ (2015),

Beroepsstandaard Geestelijk Verzorger, https://vgvz.nl/wp-content/uploads/2018/07/ Beroepsstandaard-2015.pdf.

Walton, M. (2017),

Wat maakt het verschil? Levensbeschouwelijke diversiteit in zorginstellingen, in: Religie \& Samenleving, 12 (2/3), 107-120. 